\title{
Correction to: Stress state along the western Nankai Trough subduction zone inferred from $b$-values, long-term slow-slip events, and low-frequency earthquakes
}

Keita Chiba* ${ }^{*}$

\section{Correction to: Earth Planets Space (2020) 72: 3}

https://doi.org/10.1186/s40623-020-1130-7

In the original publication of this article (Chiba 2020), the Fig. 2 should contain a color bar which explains values of catalog complete magnitude, Mc. The correct figures are below:
The original article can be found online at https://doi.org/10.1186/s4062 3-020-1130-7.

\section{${ }^{*}$ Correspondence: kchiba@sevo.kyushu-u.ac.jp}

Institute of Seismology and Volcanology, Faculty of Science, Kyushu

University, 744 Motooka, Nishi-Ku, Fukuoka 819-0395, Japan

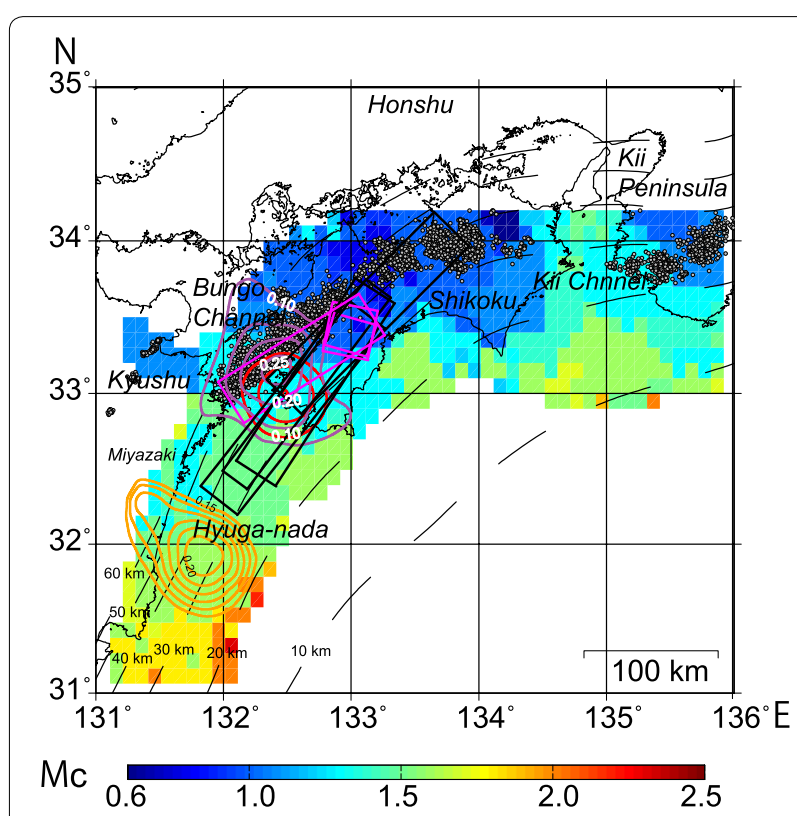

Fig. 2 Spatial distribution of catalog completeness magnitude, Mc, estimated using the maximum curvature method (Wiemer and Wyss 2000) on a grid with $0.1^{\circ}$ horizontal spacing. Events were extracted in a $35-\mathrm{km}$ radius around each node. Purple and red contours represent isoslip values due to 2003 and 2010 SSEs in the Bungo Channel (Ozawa et al. 2013; Ozawa 2017), with labels in meters and an increment of $0.05 \mathrm{~m}$. Orange contours represent the cumulative slip distribution due to 1997, 2005, 2007, and 2009 SSEs in southern Miyazaki district (Yarai and Ozawa 2013), with labels in meters and an increment of $0.01 \mathrm{~m}$. Purple and black rectangles represent faults corresponding to SSEs from 2004-2006 to 2011-2013 in western Shikoku (Takagi et al. 2016). Gray circles show LFE locations obtained from the JMA catalog
SpringerOpen

(c) The Author(s) 2020. This article is licensed under a Creative Commons Attribution 4.0 International License, which permits use, sharing adaptation, distribution and reproduction in any medium or format, as long as you give appropriate credit to the original author(s) and the source, provide a link to the Creative Commons licence, and indicate if changes were made. The images or other third party material in this article are included in the article's Creative Commons licence, unless indicated otherwise in a credit line to the material. If material. is not included in the article's Creative Commons licence and your intended use is not permitted by statutory regulation or exceeds the permitted use, you will need to obtain permission directly from the copyright holder. To view a copy of this licence, visit http://creativecommons.org/licenses/by/4.0/. 
Published online: 26 February 2020

\section{Reference}

Chiba K (2020) Stress state along the western Nankai Trough subduction zone inferred from $b$-values, long-term slow-slip events, and low-frequency earthquakes. Earth Planets Space 72:3. https://doi.org/10.1186/s4062 3-020-1130-7

\section{Publisher's Note}

Springer Nature remains neutral with regard to jurisdictional claims in published maps and institutional affiliations. 